\title{
LIMITATIONS ON THE FUNCTIONS OF THE UNITED NATIONS
}

\author{
HANS KELSEN:
}

THE general provisions of the Charter conferring functions upon the United Nations and obligations upon its members are subject to important restrictions concerning matters of domestic jurisdiction (Article 2, Paragraph 7), the right of self-defense (Article 51), and . action in relation to former enemy states (Articles 53 and 107).

\section{DOMIESTIC JURISDICTION}

Article 2, Paragraph 7 of the Charter reads as follows:

"Nothing contained in the present Charter shall authorize the United Nations to intervene in matters which are essentially within the domestic jurisdiction of any state or shall require the Members to submit such matters to settlement under the present Charter; but this principle shall not prejudice the application of enforcement measures under Chapter VII." 1

This paragraph comprises two different rules: one prohibiting intervention on the part of the Organization in matters which are essentially within the domestic jurisdiction of any state; another releasing the members to submit such matters to settlement under the Charter. The broad prohibition applies against intervention by the whole of the international organization or by any subdivision thereof. The Report to the President correctly states, "The proviso with reference to domestic jurisdiction becomes a limitation upon all of the activities of the Organization rather than merely a limitation upon the action of the Security Council under Chapter VI of the Charter. . . ." 2

Article 2, Paragraph 7 of the Charter does not refer expressly to disputes, but is phrased more generally to include all "matters." However, disputes which involve questions of domestic jurisdiction

$\dagger$ Professor of international law and jurisprudence, Department of Political Science, University of California; formerly professor of law at the Universities of Vicnna, Cologne, Prague, and at the Graduate Institute of International Studies in Geneva; Oliver Wendell Holmes Lecturer, 1940-1, Harvard University School of Law; author of numerous boots and articles in various periodicals.

1. In a statement on Art. 2, T 7, UNCIO Doc. 929, I/1/37 (1945) 1, the Delegate of Norway said, "It is tantamount to imposing on the worling of the syatem of international investigation and conciliation very severe limitations and thus to esposing the pasce of the world to dangers, the extent of which it is difficult to assess in advance. One is reminded of the caustic remark of Elihu Root, 'The people of the State of New Yorls are in favor of prohibition, but against the application of it." " See UNCIO Doc. 1019, I/1/42 (1915) 1; UNCIO Doc. 976, I/1/40 (1945) 1.

2. Report to the President on the Results of the San Franciseo Confcrenec by the Scarctary of State, Dep't of State Conference Ser. No. 71 (June 26, 1945) 43 (hereinafter cited as Report to the President). 
are manifestly within the operation of the paragraph, since only disputes could be matters submitted to settlement. The essential content of the paragraph has been taken over from Article 15, Paragraph 8 of the Covenant of the League of Nations:

"If the dispute between the parties is claimed by one of them, and is found by the Council, to arise out of a matter which by international law is solely within the domestic jurisdiction of that party, the Council shall so report, and shall make no recommendation as to its settlement."

The idea underlying this exclusion in both Charter and Covenant is that certain matters by their very nature are within the domestic jurisdiction of the states, and that a dispute which arises out of such a matter is an internal or domestic affair, involving no "international" relation, and so not calling for an international agency competent to settle the dispute. There can be little doubt that this basic idea is erroneous, whether it be particularized to mean "solely" or "essentially" within domestic jurisdiction.

The Covenant excluded from League determination disputes "solely" within domestic jurisdiction. However, there is no matter that cannot be regulated by a rule of customary or contractual international law, and if a matter is regulated by a rule of international law, it is no longer "solely within the domestic jurisdiction" of the state concerned. Matters solely within domestic jurisdiction are only those which, for the time being, are not being regulated by a rule of international law. But when a dispute between two states arises out of a matter which, according to the opinion of one of the parties, is solely within its domestic jurisdiction, the dispute is nevertheless an international dispute, and should be amenable to the established processes of international settlement. Even if the international agency (such as the Council under Article 15, Paragraph 8 of the Covenant) be competent only to decide the question whether the matter in controversy is solely within the domestic jurisdiction of one of the disputants, the decision is the settlement of a true international dispute. For an adjudication upholding a state's claim of exclusive domestic jurisdiction decides that the other state may not, under international law, interfere in the matter. A contrary decision means that the state which opposes its domestic jurisdiction to the other party's claim is wrong, according to international law, at least in so far as the jurisdictional objection is not justified. Consequently, the power to determine when a disputed matter is solely within domestic jurisdiction implies the power to settle the dispute.

Substitution of "essentially" for "solely" to limit the scope of domestic jurisdiction does not rectify the error. One state's claim that a contested matter is within its domestic jurisdiction may give rise to 
an international dispute under either terminology. Just as there are no matters which, by their very nature, are "solely" within the domestic jurisdiction, so there are no matters which by their nature are "essentially" within that jurisdiction. The fact that such matters as form of government, acquisition or loss of citizenship or immigration are not normally regulated by a rule of international law is no reason to assume that they are "essentially" within the jurisdiction of states; they can be the object of treaty. From this it follows that the question is not the nature of a disputed matter but whether customary or contractual international law has left the matter solely within domestic jurisdiction, ${ }^{3}$ or has subjected states to international obligations in the matter. (Thus the omission of reference to international law in Article 2, Paragraph 7 of the Charter effects no material change from Article 15, Paragraph 8 of the Covenant.) In marked contrast to the Covenant, the Charter does not contain a provision conferring on any organ power to determine whether a matter is within the domestic jurisdiction of a state. Consequently, the provision that a member is not obliged to submit a matter which is essentially within its domestic jurisdiction to settlement under the Charter may be interpreted to mean that the member itself has the power to decide whether the matter is essentially within its domestic jurisdiction. If this interpretation is accepted, then replacement of the term "solely" by the term "essentially" marks further deviation from the Covenant, since a member may claim "essentially" domestic jurisdiction even though the matter is regulated by international law and an allegation of "solely" domestic jurisdiction would be untenable."

3. At the Seventeenth Meeting of Committee I/1, UNCIO Doc. 1019, I/1/42, at 5 , the Belgian Delegate said that an international treaty does not automatically bring its substance into the realm of international law.

4. During the discussion of Art. 2, $\$ 7$, at the Seventeenth Meeting of Committce I/1, UNCIO Doc. 1019, I/1/42 (1945) 5 el seq., the Delegate of Australia declared with regard to the substitution of the word "essentially" for "solely," that he agreed with the opinion, expressed previously by the Delegate of the United States, "that matters solely within domestic jurisdiction were constantly contracting. For example, international agreement to promote full employment would have been unheard of a few years ago and even now, although this matter remained within domestic jurisdiction, it was not 'solely' within domestic jurisdiction. It was, however, 'essentially' within domestic jurisdiction and that was a better criterion to apply." Consequently, in spite of the fact that a dispute refers to the obligation assumed by an international treaty, an intervention in this dispute on the part of the Organization is excluded if the international obligation refers to a subject matter which is "essentially" within the domestic juriediction. Since this can be said of almost every subject matter, Art. 2, ๆ 7 may be used as an instrument to paralyze an important part of the activity of the Organization.

The Report to the President at 45, justifies the replacement of the term "solely" by the term "essentially" as follows: "It seemed more appropriate to look to what was the ersence, the heart, of the matter rather than to be compelled to determine that a certain matter was 'solely' domestic in character." Neither by its very nature nor for the reason that inter- 
The stipulation of Article 2, Paragraph 7 of the Charter that, where disputes arise from matters within domestic jurisdiction, members are not obliged to submit such disputes "to settlement under the present Charter" ostensibly means that they are not obliged to refer such disputes to the Security Council (Article 37, Paragraph 1) and are not obliged to accept intervention in such disputes on the part of the General Assembly (Articles 10,11) or of the Security Council (Article 33, Paragraph 2; Articles 34,36) or even of the International Court of Justice (Article 36, Paragraphs 2-6 of the Statute). ${ }^{6}$ However, the stipulation is broader than if it had read "to submit such matters to settlement through organs of the United Nations." Accordingly, the domestic jurisdiction clause may be interpreted to mean that members are not obligated to settle such disputes by peaceful

national law does not establish certain obligations with respect to it, a matter is "essentially" domestic in character. As far as the reference to "international law" is concerned, which c. VIII, $\$ A, ~ \Uparrow 7$ of the Dumbarton Oaks Proposals had taken over from Art. 15, If 8 of the Covenant, but which in the text of Art. 2, I 7 of the Charter has been dropped, the Report to the President at 44 et seq. states, "This deletion was supported by the argument that the body of international law on this subject is indefinite and inadequate. To the extent that the matter is dealt with by international practice and by text writers, the conceptions aro antiquated and not of a character which ought to be frozen into the new Organization." As to the question whether a rule of general customary international law or an international treaty imposes upon the state which considers a matter to be within its domestic jurisdiction a definite obligation with respect to this matter, "the body of international law" is neither "indefinite" nor "inadequate." The question, as to whether a State is under an obligation imposed upon it by international law, is to be answered in almost any dispute. If the "body of international law" were really so "indefinite and inadequate" that it would be justified to ignore it, no dispute could be decided in accordance with international law.

5. The wording of Art. 2, II 7 does not prevent a state which has declared, under Art. 36, I 2 of the Statute of the International Court of Justice, that it recognizes as compulsory the jurisdiction of the Court in the legal disputes referred to in this paragraph from declining the jurisdiction of the Court by claiming that the dispute arises out of a matter which is essentially within the domestic jurisdiction of that state. The only question is whether, in case the other party contradicts this view, paragraph 6 of Article 36 applies providing that the Court shall settle the matter. Even if the answer is in the affirmative, the Court is bound by Article 2, paragraph 7 of the Charter and consequently has to recognize a matter to be essentially within the domestic jurisdiction of the state which, under this provision of the Charter, declares the matter to be essentially within its domestic jurisdiction. That means that Article 2, paragraph 7 of the Charter may deprive a declaration made under Article 36, paragraph 2 of the Statute of almost all its value.

The Resolution 196 adopted by the United States Senate on August 2, 1946 (Congressional Record, Vol. 92, No. 154, p. 10850), authorizing the President of the United States to deposit with the Secretary-General of the United Nations a declaration under paragraph 2 of Article 36 of the Statute of the International Court of Justice, contains the provision that the declaration shall not apply to "disputes with regard to matters which are essentinlly within the domestic jurisdiction of the United States as determined by the United States." This provision is in conformity with the Charter. Even without it, the declaration of the United States made under Article 36, paragraph 2 of the Statute could not have the effect to oblige the United States to submit to the Court a legal dispute which the United States considers to refer to a matter essentially within its own domestic jurisdiction. 
means, in accordance with the principle laid down in Article 2, Paragraph 3 of the Charter. Such an interpretation could be reinforced by reference to the basic idea that a matter within domestic jurisdiction of a state cannot give rise to an "international" dispute, while Article 2, Paragraph 3 obligates members to settle by peaceful means only their "international" disputes.

It is true that in Chapter VI, entitled "Pacific Settlement of Disputes," Articles 33 to 38 refer to "disputes" and not to "international disputes." However, it might be maintained that, after Chapter I of the Charter established the kind of disputes which are to be settled by peaceful means (namely, "international" disputes in the sense of Article 2, Paragraphs 3 and 7), it was deemed superfluous to repeat in the subsequent Chapters the adjective "international," since it was considered to be self-evident that the disputes referred to in subsequent Chapters, and especially in Chapter VI, are the same as those referred to in Chapter $\mathrm{I}$.

To carry the argument further: if a dispute is not "international," then the relation between the disputing states is not an "international" relation; ${ }^{6}$ therefore the principle that members shall refrain from threat or use of force "in their international relations" (Article 2, Paragraph 4) does not apply where the dispute arises out of a matter which is within the domestic jurisdiction of one of the disputants; consequently, members may settle such disputes by threat or use of force.

Textual deficiencies in the Covenant of the League of Nations posed the question whether, under Article 15, Paragraph 8 , states were allowed to resort to war to settle a dispute which arose out of a matter solely within the domestic jurisdiction of one party. It was possible to argue: since Article 15, Paragraph 8 does not expressly forbid waras the Covenant does in Article 15, Paragraph 6 -the parties are allowed to resort to war. It was also possible to argue: since Article 15, Paragraph $\delta$ does not expressly allow war-as does Article 15, Paragraph 7 -the parties are forbidden to resort to war. The latter interpretation could be further strengthened by the argument that assertion of domestic jurisdiction constituted a valid defense to a disputed claim only if confirmed by the Council. Such confirmation implied that the party asserting domestic jurisdiction was right, and demands by the other party were unjustified. It would be absurd for the Cove-

6. With reference to Art. 2,77 , the Delegate of Australia expresced the opinion that an organization "that is genuinely international in character" should not be permitted "to intervene in those domestic matters in which, by definition, international law promits each state entire liberty of action." UNCIO Doc. 969, I/1/39 (1945) 2. He spolse of "a matter of legitimate 'international' and not merely of 'domestic' concern." Id. at 4. Thus he interpreted the term "domestic" to mean the opposite of "international." 
nant to authorize a member to resort to war against another member whose right had been sustained by a decision of the Council.

Unlike the Covenant, the Charter does not undertake to authorize or prohibit war in stated circumstances, but contains a general prohibition of the use of force. Consequently, the use of force may be considered as allowed only if an exception to this rule is expressly stipulated. As indicated previously, Article 2, Paragraphs 3, 4 and 7 may be interpreted as establishing such an exception with respect to disputes arising out of matters within the domestic jurisdiction of a state. Furthermore, since the Charter does not empower any international agency to decide whether the subject matter of the dispute is within domestic jurisdiction, it appears that if one party to a dispute declares the matter out of which the dispute has arisen to be essentially within its domestic jurisdiction, the dispute is outside the jurisdiction of the United Nations. ${ }^{7}$ It is, therefore, possible to conclude that Article 2, Paragraph 7 establishes the circumstances in which members may use force without violating the Charter.

So interpreted, Article 2, Paragraph 7 probably goes much further than the intention of those who drafted it. ${ }^{8}$ It is very likely that the authors of the Charter did not intend that Paragraph 7 should release

7. At the Seventeenth Meeting of Committee I/1, UNCIO Doc. 1019, I/1/42, at 3, the Delegate of Greece declared "that the basic issue was one of determining what was domestic jurisdiction; his Delegation felt that the International Court was the body which should determine this matter." He suggested the following amendment: "It should bo left to the International Court of Justice at the request of a party to decide whether or not such situation or dispute arises out of matters that under international law fall within the domestic jurisdiction of the State concerned." In reply to the arguments advanced in favor of the Greek amendment, Mr. Dulles (U.S.A.) commented that "disputes involving interpretation viere not peculiar to Art. 8, and that it was unnecessarily limited to place the proposed revision in one article. For example, Art. 5 of Chapter II stated that the 'Organization shall give every assistance,' but there might be a question as to what constituted 'every assistanco' or whether a state was giving 'every assistance.' Shall it be the Court or the Council? Some body would have to determine questions such as this. The committees of Commission IV had been studying this very type of problem, but they were not prepared to say that all matters of this kind should be referred to the International Court for settlement. It would hardly seem possible or desirable to introduce into Chapter II the principle of 'compulsory jurisdiction' for the Court when another branch of the Conference had rejected this principle as impractical of adoption at the present time." For the Belgian Delegate's suggested formulation of Art. 2, I 7, see id. at 4; for reasons behind Uruguay's vote in favor of Greek and Belgian proposals, see UNCIO Doc. 1167, I/10 (1945) at 3.

8. The Report to the President at 45, states, "It is quite conceivable that there might be an international dispute with reference to such matters as tariff, immigration, or the like, but where such a dispute relates to matters which are essentially domestic in character, settlement through international processes should not be required." Does this follow even if an international treaty imposes upon one party to the dispute a definite obligation with respect to the tariff or immigration matter which is the object of the dispute? If the disputo is "international," why should settlement through international processes not be required? See UNCIO Doc. 969, I/1/39 (1945) 3 et seq. 
members from the obligation to refrain from the threat or use of force in the settlement of a conflict arising out of a matter which, in the opinion of a member, is essentially within its domestic jurisdiction. Probably it was only intended to release the member from its obligation to submit the dispute to the Secunty Council. Hovever, if such was the intention, it does not appear in the text of the Paragraph.

After the categorical exclusion of any intervention on the part of the United Nations in matters essentially within the domestic jurisdiction of any state, Article 2, Paragraph 7 declares "but this principle shall not prejudice the application of enforcement measures under Chaptcr VII." Since enforcement measures under Chapter VII constitute the most extreme methods of intervening in the affairs of the members, this clause must be interpreted as restricting the basic principle of non-intervention in the domestic sphere. The question now becomes: what acts of intervention are permitted? Does "enforcement measures" mean only measures involving the use of armed force, as determined in Article 42, or does the term include measures taken in accordance with Article 41, not involving the use of armed force? It is probable that the latter interpretation corresponds to the intention of those who drafted the Charter. If so, the following acts of intervention are excluded by Article 2, Paragraph 7: recommendations of the General Assembly (Article 10; Article 11, Paragraph 2; and Article 14); calling upon the parties on the part of the Security Council to settle their disputes by peaceful means of their own choice (Article 33, Paragraph 2); investigation of the dispute or situation by the Security Council (Article 34); determination by the Security Council whether the continuation of the dispute or situation is likely to endanger the maintenance of international peace and security (Article $34)$; recommendation of appropriate procedures or methods of adjustment by the Security Council (Article 36, Paragraph 1; Article 37, Paragraph 2); recommendation of terms of settlement by the Security Council (Article 37, Paragraph 2); determination by the Security Council of the existence of any threat to the peace, breach of the peace, or act of aggression and recommendations applying thereto (Article $39) ;{ }^{9}$ and preventive measures (i.e., calling upon the parties to comply with provisional measures) by the Security Council (Article 40).

There can be no doubt that the continuation of a dispute arising

9. According to the amendment suggested by the sponsoring governments, the eccend sentence of Art. 2, If 7 reads as follows: "But this principle shall not prejudice the applisation of chapter VIII, Section B [of the Dumbarton Oalis Proposals, Chapter VII of the Charter]." Under this provision, recommendations under Art. 39 vere poscible. In order to exclude such recommendations, upon a motion of the Australian Delegation, the words "application of Chapter VIII, Section B" were replaced by the words "enforcement measures under Chapter VIII, Section B." Compare Amendment by the Australian Delegation to Proposed Paragraph 8 of Chapter II (Principles), UNCIO Doc.969, I/1/39 (1945). 
out of a matter which, according to the opinion of one of the contesting parties, is essentially within its domestic jurisdiction, may endanger the maintenance of international peace and security. However, if Article 2, Paragraph 7 is taken literally, the Security Council is not allowed to investigate such a dispute to determine whether its continuance is likely to endanger the maintenance of international peace and security, pursuant to Article 34, since this is not an enforcement measure, although the Security Council may decide to take enforcement measures pursuant to Articles 41 and 42 . This interpretation of Article 2, Paragraph 7 is further reduced to absurdity by consideration of Article 39, which reads:

"The Security Council shall determine the existence of any threat to the peace, breach of the peace, or act of aggression and shall make recommendations, or decide what measures shall be taken in accordance with Articles 41 and 42, to maintain or restore international peace and security."

This Article must be interpreted to mean that, before making recommendations or deciding upon measures under Articles 41 and 42, the Security Council must determine the existence of a threat to the peace, a breach of the peace, or an act of aggression. Such determination is not, in itself, an enforcement measure under Chapter VII, and so outside the permitted field of intervention in matters within domestic jurisdiction.

In the light of this analysis, it seems hardly possible to interpret literally the final clause of Article 2, Paragraph 7. If intervention by enforcement measures under Chapter VII in matters of domestic jurisdiction is allowed, then, logically, intervention by determining the existence of a threat to the peace, breach of the peace, or act of aggression in such matters of domestic jurisdiction must be allowed as well. Apparently, therefore, the word "enforcement" in the clause is superfluous since the Security Council may take other than merely enforcement measures under Chapter VII.

Accordingly, it appears that the Security Council in matters of domestic jurisdiction is allowed to determine the existence of a threat to the peace, but is not allowed to investigate a dispute to determine whether its continuance is likely to endanger the maintenance of international peace and security; is allowed to take enforcement action, but is not allowed to recommend procedures or methods of adjustment and terms of settlement. Whether such tenuous distinctions can be observed in practice remains to be seen. The enforcement measures under Chapter VII are probably intended to be "sanctions," similar to the enforcement measures provided by Article 16 of the Covenant of the League of Nations. However, the enforcement measures authorized by the Charter go beyond the legal concept of sanctions as 
reactions against violation of obligations and tend toward being political measures. The conditions under which the Security Council is authorized to take enforcement measures, especially the condition formulated as "threat to the peace," are not identical with a member's violation of its obligation to refrain from threat or use of force (Article 2, Paragraph 4). As a "threat to the peace," the Security Council may consider conduct of a member which is neither a threat or a use of force as, for instance, non-compliance with a recommendation of the Security Council or of the General Assembly, although such noncompliance does not violate obligations of the member expressly stipulated by the Charter. If the Security Council has determined the existence of a threat to the peace, breach of the peace, or act of aggression-and in this determination it is untrammeled by definitions-, it may take enforcement action in whatever direction it deems necessary to maintain or restore peace; the Charter does not bind the Security Council to direct enforcement action only against a state which has violated its obligation to refrain from threat or use of force, or even only against a state which is guilty of a threat to the peace, breach of the peace, or act of aggression. If the interpretation of Article 2, Paragraph 7 already outlined is accepted, a member which, in a dispute arising out of a matter of domestic jurisdiction, does not submit the matter to settlement under the Charter but settles the dispute by threat or use of force, does not violate an obligation imposed upon it by the Charter, but nevertheless exposes itself to enforcement action taken by the Security Council-not as a legal sanction, but as a political measure.

Under Article 2, Paragraph 7, as well as under Article 39, the Organization is authorized, but not obliged, to intervene with enforcement measures in matters of domestic jurisdiction. Consequently, the Security Council may, for political or other reasons, refrain from intervening even in case of threat or use of force. In general, inactivity of the Security Council does not justify resort to self-help by the parties to a conflict. Under Article 51 they are allowed to do so only as reaction against "armed attack." If, however, the conflict arises out of a matter which is within the domestic jurisdiction of a state, and if the members are not obliged to refrain from threat or use of force in matters which are essentially within their domestic jurisdiction, then any party to the conflict may resort to self-help without violating the Charter, even before being attacked.

Furthermore, as Article 2, Paragraph 7 now stands, conflicts which arise out of a matter of domestic jurisdiction may remain in legal stalemate unless the disputants resort to arms. If a member refuses to settle a dispute under Article 33, Paragraph 1, claiming the matter to be essentially within its domestic jurisdiction, and if the other party nevertheless refers the dispute to the Security Council under Article 37 * 
Paragraph 1, the Council can intervene only if it assumes the power to decide whether the matter is essentially within the domestic jurisdiction of the member so claiming. Such assumption of power would be in disregard of the words of the Charter.

However, if the enforcement measures provided in Chapter VII are intended to be legal sanctions, one may assume that the members are not only under the obligation to "refrain from the threat or use of force" (Article 2, Paragraph 4) but also under the obligation to refrain from any action which may be considered by the Security Council to be a "threat to the peace, breach of the peace, or act of aggression" (Article 39). The latter obligation, as a condition to use of enforcement measures, would be broader than the former and not subject to the distinction between "international relations" and "domestic matters." The consequence of such an interpretation would be that even in a matter of domestic jurisdiction the obligation to refrain from any threat to the peace, breach of the peace, or act of aggression would prevail. If it is further assumed that the Security Council, in spite of the wording of Article 2, Paragraph 7, is authorized to determine the violation of this obligation in case of a dispute arising out of a matter of domestic jurisdiction, the Security Council may consider refusal to settle the conflict by pacific means (Article 33, Paragraph 1) as a "threat to the peace" and take enforcement action against the member concerned. It is obvious such an interpretation would largely neutralize the effect of Article 2, Paragraph 7.

The general prohibition against intervention in matters of domestic jurisdiction may be of great importance in relation to the functions of the Organization under Chapters IX and X. Article 55 authorizes the United Nations to promote:

" $a$. higher standards of living, full employment, and conditions of economic and social progress and development;

$b$. solutions of international economic, social, health, and related problems; and international cultural and educational cooperation; and

c. universal respect for, and observance of, human rights and fundamental freedoms for all without distinction as to race, sex, language, or religion."

Article 62, Paragraphs 1 and 2 provide:

"1. The Economic and Social Council may make or initiate studies and reports with respect to international economic, sacial, cultural, educational, health, and related matters and may make recommendations with respect to any such matters to the General Assembly, to the Members of the United Nations, and to the specialized agencies concerned.

2. It may make recommendations for the purpose of promoting 
respect for, and observance of, human rights and fundamental freedoms for all."

It is hardly possible to fulfill these functions effectively without intervening in matters of domestic jurisdiction. Further, under Article 56 the members are obliged "to take joint and separate action in cooperation with the Organization for the achierement of the purposes set forth in Article 55." These provisions are hardly consistent with Article 2, Paragraph 7. ${ }^{10}$

\section{SELF-DEFENSE}

Although the right of self-defense is presumably established by a rule of general international law which has the character of jus cogens so that it cannot be affected by any treaty, it was considered not superfluous to stipulate this right expressly in the Charter. Neither the Covenant of the League of Nations nor the Pact of Paris ${ }^{11}$ contained an analogous provision. Article 51 of the Charter runs as follows:

"Nothing in the present Charter shall impair the inherent right of individual or collective self-defense if an armed attack occurs against a Member of the United Nations, until the Security Council has taken the measures necessary to maintain international peace

10. In the Hearings before the Committee on Forcign Relations, Urited Stales Serate, or the Charter of the United Nations (hereinafter cited as Hearings) (1945) 307, Mr. Pasvolsly, Special Assistant to the Secretary of State, made the following statement: "The langusge of chapter IX is very strong and very far-reaching; and questions were raiscul in the diseussion as to whether or not the language used could in any way be interpreted as meaning interference in the domestic affairs of the Member States. It was quite clear that the principle regarding domestic jurisdiction already inserted in the Charter would be governing. However, in view of the importance of this particular question, the committee agreed to include in its records the following statement: "The Members of Committee 3 of Commission II are in full agreement that nothing contained in chapter IX can be construed as giving authority to the Organization to intervene in the domestic affairs of Member States." " That means that Committee II/3 interpreted Art. 55 as being restricted by Art. 2, I 7, but an interpretation according to which Art. 2, 77 is restricted by Art. 55 is not excluded. In the Hearings Senator Millikin asked, "I notice several reiterations of the thought of the Charter that the Organization shall not interfere with domestic affairs of any country. How can you get into these social questions and economic questions without conducting investigations and malsing inquiries in the various countries?" To this Mr. Pasvolsky answered, "The question of what matters the Organization would be concerned with would depend upon whether or not they had international problems. International problems may arise out of all corts of circumstances."

The ensuing discussion shored clearly that the principle of non-intervention in domestic affairs-however this concept may be defined-is hardly compatible with the functions the Charter confers upon the Organization in cc. $I X$ and $X$.

11. In his speech of March 15, 192S, before the Council on Foreign Relations, New York (published as Special Supplement to [1928] 6 Foreigri Afrairs, Spec. Supp. No. 3) Mr. Kellogg declared, "This right [of self-defense] is so inherent and universal that it was not deemed necessary even to insert it expressly in the treaty." 
and security. Measures taken by Members in the exercise of this right of self-defense shall be immediately reported to the Security Council and shall not in any way affect the authority and responsibility of the Security Council under the present Charter to take at any time such action as it deems necessary in order to maintain or restore international peace and security."

This provision presupposes the existence of the right of self-defense as established not by positive international law but by natural law, for it speaks of an "inherent" right. This is a theoretical supposition of the legislator which has no legal importance since the effect of Article 51 would not change if the term "inherent" were dropped. By declaring that nothing in the Charter shall impair the inherent right of self-defense, the Charter confers such right upon the members, whether or not established by positive general international law or by natural law. In this connection, the right of self-defense means the authorization of the members to use force in order to defend themselves against an armed attack. However, the Charter does not consistently maintain the presupposed idea of an "inherent" right of self-defense, which cannot be altered by positive law. For the Charter both extends and limits the availability of self-defense.

The right of self-defense, according to the natural law doctrine, is the right of an individual or a state to defend his person, property, or honor against a real or imminent attack. It is a right of the attacked or threatened individual or state, and of no other individual or state. Article 51 confers the right to use force not only upon the attacked state but on other states which unite with the attacked state in order to assist it in defense. If this is the meaning of the term "collective self-defense," the term is not quite correct, for the Charter authorizes collective "defense," but not collective "self-defense." Collective defense exists when two or more states conclude a treaty obliging or authorizing the contracting parties to assist one another in case one of them is attacked by a third state. The action on the part of the states which are not attacked but only assist the attacked state against its aggressor is not exactly "self"-defense.

According to Article 51 treaties of assistance for the purpose of collective defense are allowed. The action characterized by Article 51 as "collective self-defense" may be a collective enforcement action, organized by such treaties of assistance, to be taken against the state guilty of an armed attack against one of the contracting parties. Such enforcement action may be very similar to the enforcement actions which the Security Council is authorized to take against aggressors under Article 39.

The wording of the first sentence of Article 51 seems to authorize such treaties of assistance to be concluded not only between members but also between members and non-members. But the second sentence 
refers only to "measures taken by Members in the exercise of this right of self-defense." Hence the interpretation is possible that the term "collective self-defense" covers only treaties of assistance concluded between members for the purpose of defense. However, if Article 2, Paragraph 6 is to be interpreted to mean that the obligation to refrain from threat and use of force is imposed also upon non-member states, it may be assumed that the right of self-defense as stipulated in Article 51 cannot be denied to non-members, and that the Security Council is authorized to ensure that non-members report to the Security Council, in accordance with the second sentence of Article 51 the measures they have taken in the exercise of this right. For this is certainly "necessary for the maintenance of international peace and security." That being so, there is no reason to deny to members the right to conclude treaties of assistance with non-member states for protection against armed attack.

Such treaties of assistance may be regional arrangements referred to in Article 52.12 If so, the rule of Article 53, Paragraph 1 that "no enforcement action shall be taken under regional arrangements or by regional agencies without the authorization of the Security Council" must be interpreted not to refer to enforcement actions taken under Article 51, so that the exception mentioned in Article 53 ("measures against enemy states") is not the only exception to the rule of that Article.

It is doubtful whether the term "collective" self-defense necessarily means that the defense must be organized prior to the aggression by an international treaty. It is not impossible to interpret the term to mean that any member is authorized to assist an attacked member in its self-defense without having previously concluded with the attacked state a treaty of assistance.

It is hardly possible to consider the right or the duty of a nonattacked state to assist an attacked state as an "inherent" right, that is to say, a right established by natural law. On the other hand, the Charter restricts the right of self-defense by stipulating that the right applies only against "an armed attack" and only as long as the Security

12. Such a regional arrangment is the Declaration on Reciprocal Accistance and American Solidarity, the so-called Act of Chapultepec, adopted by the Governments Represented at the Inter-American Conference on Problems of War and Peace, Mexico City, on March 6, 1945. The fourth clause of Part I of this Act reads as follows: "The Governments Represented at the Inter-American Conference on Problems of War and Peace Declare: That in case acts of aggression occur or there are reasons to believe that an aggression is being prepared by any other state against the integrity or inviolability of the territory, or against the sovereignty or political independence of an American State, the States eignatery to this Act will consult amongst themselves in order to agree upon the measures it may be advieable to take." However, measures involving the use of force may be talien in conformity with Art. 51 of the Charter only against an "armed attacl," not in any case of agression or in case "there are reasons to believe that an aggression is being prepared." 
Council "has not taken the measures necessary to maintain international peace and security." It is of importance to note that Article 51 does not use the vague term "aggression" but the much narrower concept of "armed attack," which means that merely "imminent" at tack or any act of aggression which has not the character of an attack involving the use of armed force does not justify resort to force as an exercise of the right established by Article $51 .{ }^{13}$ The attacked state and its allies have to stop the use of force as soon as the Security Council has taken the necessary measures, unless these measures involve enforcement action ordered by the Security Council to be taken by the attacked state or its allies.

In order to enable the Security Council to take on time the measures necessary to maintain international peace and security, "measures taken by Members in the exercise of this right of self-defense shall be immediately reported to the Security Council." Reported by whom? Probably by the states which have taken the measures. If this is the intended meaning of the sentence, it would have been correct to say: the states which exercise this right of self-defense shall immediately report the measures taken by them to the Security Council, for it is obviously intended to establish an obligation of the members (and through Article 2, Paragraph 6, of non-member states) to report to the Security Council.

The obligation to stop the exercise of the right of self-defense is conditioned by the requirement that the Security Council first take "the measures necessary to maintain international peace and security." It is significant that Article 51 does not provide "until the Security Council has taken enforcement action against the state guilty of an armed attack." The Security Council may take any "measures necessary to maintain international peace and security,"-"to maintain," and not as it is usually formulated "to maintain or to restore international peace and security," although in case an "armed attack" has occurred and thus peace has been broken, only "to restore" and not "to maintain" peace seems to be possible. Who is competent to decide the question whether the Security Council has taken the measures "necessary" to maintain international peace and security? The Security Council exclusively, or the member or members exercising the right of self-defense? The Charter does not say in the first sentence of Article 51-as it says in the last sentence- "measures which the Security Council deems necessary." It does not, therefore, exclude an interpretation of the first sentence according to which a member is not obliged to cease to exercise its right of self-defense when it has reported

13. It is therefore hardly possible to interpret Art. 51 to mean that it does not affect the validity of the Monroe doctrine, a provision expressly inserted in the Covenant of the League (Art. 21). See Hearings at 649 et seq. 
to the Security Council and the Security Council has taken measures which, in the opinion of the member, are not the measures "necessary to maintain international peace and security." This interpretation may be confirmed by the doctrine that the right of self-defense is conferred upon the states by a rule of general international law which has the character of jus cogens. The opinion of the rictim of the illegal attack may be quite different from the opinion of the Security Council about the measures which are "necessary" in the case concerned. It was probably not the intention of the legislator to confer upon the attacked member the power to decide whether the measures taken by the Sicurity Council are adequate. The idea was probably that a member is allowed to exercise its right of self-defense until the Security Council has taken the measures which the Security Council deems necessary to restore peace. But this idea is not unambiguously expressed in Article 51. ${ }^{14}$

Any decision of the Security Council to take measures necessary for the maintenance or restoration of peace, and especially the decision to take enforcement measures requires an affirmative vote of seven members including the concurring votes of the permanent members (Article 27, Paragraph 3). This provision makes it possible that even in case of armed attack referred to in Article 51, no decision of the Security Council can be reached. In case a state which has a permanent seat in the Security Council is the aggressor, such a decision is practically excluded. Hence, the right of individual and collective selfdefense as established by Article 51 may play a greater role than might be expected within an organization whose main purpose it is to male the exercise of this right superfluous. ${ }^{15}$

Since the exercise of the right of self-defense must, according to the first sentence of Article 51, cease at the very moment the Sacurity Council is taking the measures necessary to maintain peace, the provision of the second sentence that measures taken by members in the exercise of the right of self-defense "shall not in any way affect the

14. The Britisiz Commentary on the Charter of the Unilcd Nations Ipresented by the Secretary of State for Foreign Affairs to Parliament by Command of His Majesty, Cmd. 6666, London (1945) 9] states with reference to Art. 51, "It will be for the Security Council to decide whether these measures have been taken and whether they are adequate for the purpose. In the event of the Security Council failing to take any action, or if such action as it does take is clearly inadequate, the right of self-defence could be involied by any Member or group of Members as justifying any action they thought fit to take." If it is for the Socurity Council to decide whether the measures taken by it are adequate, it is not posible that an action taken by the Security Council can be declared (by whom?) as "clearly inadequate"

15. At the Twentieth Meeting of Committee III/1, UNCIO Dac. 967, III/1/43 (1945) 3 , the Delegate of the United States observed "that if a major power became the aggressor, the Council had no power to prevent war. In such case the inherent right of self-defense applied, and the nations of the world must decide whether or not they would go to war." 
authority and responsibility of the Security Council under the present Charter to take at any time such action as it deems necessary in order to maintain or restore international peace and security," seems to be superfluous. That the Security Council is authorized in case of an armed attack to take "at any time such action as it deems necessary in order to maintain or restore international peace and security," follows from the first sentence of Article 51. It could be objected that the first sentence refers only to the "authority," not to the "responsibility" of the Security Council to take at any time such action as it deems necessary. But the "responsibility" of the Security Council to take such action is sufficiently established by other provisions of the Charter (e.g., Articles 24 and 39).

\section{Action in Relation to Former Enemy States}

Article 107 constitutes an important restriction on the obligations of the members, especially on their obligation to refrain from the threat or use of force, as well as on the functions of the Organization. This Article runs as follows:

"Nothing in the present Charter shall invalidate or preclude action, in relation to any state which during the Second World War has been an enemy of any signatory to the present Charter, taken or authorized as a result of that war by the Governments having responsibility for such action."

The Article refers to action directed against ex-enemy states. Any action, especially action taken by force forbidden by the Charter, is not forbidden if directed against an ex-enemy state. This action is limited in so far only as it should be "a result" of the Second World War and "taken or authorized by the Governments having responsibility for such action." But what is the meaning of action "taken or authorized as a result of that war," and which governments have responsibility for such action? The most reasonable answer to these questions would be: action authorized by armistice, surrender, or peace treaties, action for which the states that are parties to these arrangements have responsibility. But such restriction of the action referred to in Article 107 is not stipulated. ${ }^{16}$ The Report of Committee 3 to Commission III on Chapter XII (Dumbarton Oaks Proposals, corresponding to Chapter XVII of the Charter) contains the following statement of the Delegate of the United Kingdom: "It would be impossible to limit this action, as proposed by the Australian Delegate, to that decided upon in an armistice, a peace treaty, or a joint declaration like the Declaration of Moscow because responsibility, as envisaged in Paragraph 2 (of Chapter XII of the Dumbarton Oaks Proposals,

16. See UNCIO Doc. 765, III/3/39 (1945) 4 . 
corresponding to Article 107 of the Charter) could fall upon a state which is party to none of these acts." 17 Another document of this Committee contains the following statement: "[The United Fingdom Delegate] . . . said that it would be unwise to limit the definition of the expression 'Governments having responsibility for such action' to governments parties to armistice terms, peace treaties, and the Moscow Declaration. It was conceivable that in some cases there would be no peace treaty and that a government which had not been a party either to the Noscow Declaration or to an instrument of surrender might be called upon to assume some degree of responsibility for action in regard to an enemy state." 18

The result of the negotiations in the Committee was that neither the formula defining the action referred to in Article 107 nor one delineating the governments responsible for such action has been inserted in the text of the Article. According to its wording, any action against exenemy states is permitted to any government, if the action can be justified as a result of World War II. Since Article 107 does not restrict the action to action authorized by any special agreement and since no special authority is designated to decide the question as to whether an action is to be considered as "a result of the Second Morld War," the decision of this question is left to the government which takes the action or authorizes another government to take it. ${ }^{10}$ That means that the formula "as a result of that war" does not imply" any serious restriction.

Even the slight restriction established by the phrase "taken or authorized as a result of that war" is eliminated in case enforcement action is taken against an ex-enemy state under regional arrangements or by regional agencies. Article 53, Paragraph 1 stipulates,

"The Security Council shall, where appropriate, utilize such [as referred to in Article 52] regional arrangements or agencies for enforcement action under its authority. But no enforcement action shall be taken under regional arrangements or by regional agencies without the authorization of the Security Council, with the exception of measures against any enemy state, as defined in paragraph 2 of this Article, provided for pursuant to Article 107 or in regional arrangements directed against renewal of aggressive policy on the part of any such state, until such time as the Organization may, on request of the Governments concerned, be charged with the responsibility for preventing further aggression by such a state." =3

This Article authorizes regional agencies and states under regional

17. UNCIO Doc. $1095, \mathrm{III} / 3 / 50$ (1945) 4.

18. UNCIO Doc. $1161,111 / 3 / 53$ (1945).

19. UNCIO Doc. 1095, III/3/50 (1945) 4 .

20. Ibid. 
arrangements to act against ex-enemy states as they are authorized to act by Article 107. In addition to this it authorizes regional agencies and states under regional arrangements to resort to force against exenemy states for a purpose which is defined by the terms "against renewal of aggressive policy." That means: prevent the renewal of ag. gressive policy as well as react against an actual attempt to renew aggressive policy. The question as to what circumstances justify such action against an ex-enemy state has to be decided by the regional agency or the individual states acting under a regional arrangement. Such regional arrangement frees the states from the restriction established by the terms of Article 107, "as a result of that war;" unless "renewal of aggressive policy on the part of [an ex-enemy] state" is considered to be always "a result of that war."

This far-going authorization of regional organizations to resort to force against ex-enemy states is limited by Article 53 only temporarily, "until such time as the Organization may, on request of the Governments concerned, be charged with the responsibility for preventing further aggression by such a state." It depends on the discretion of the governments concerned to make such a request. The Organization is authorized to accept the charge. That such acceptance is required follows from the use of the term "request." The acceptance of the request constitutes an agreement between the Organization and the government making the request. The Charter does not determine the organ of the United Nations to which the request shall be addressed, and which is competent to accept it. Since enforcement action is involved, it may be assumed by analogy that the Security Council is competent to act on behalf of the Organization under Article 53, Paragraph 1. According to the wording of this provision, the Organization is authorized to accept the responsibility for preventing further aggression on the part of the ex-enemy state. That means that the power of the regional agency or the parties to a regional arrangement to take enforcement action against renewal of aggressive policy on the part of an ex-enemy state may be transferred to the Organization. No such possibility is provided for with respect to the power, conferred upon the members by Article 107, to take enforcement action against enemy states "as result of that war."

It must be noted that the power conferred upon the Organization by the request accepted under Article 53, Paragraph 1 (to take enforcement action against renewal of aggressive policy on the part of an exenemy state) is greater than the power conferred upon the Organization by Article 39 of the Charter. Just as the Government concerned, the Organization, after having accepted the former's request under Article 53, Paragraph 1, is not bound to determine the existence of a threat to the peace, breach of the peace, or act of aggression before taking enforcement action. Article 53, Paragraph 1 does not refer to 
Article 39 . Hence the enforcement action taken by the Organization under Article 53, Paragraph 1 is not restricted by the provision of Article 39.

Within the problematic restrictions established by Articles 107 and 53, the members of the United Nations are not obliged by the Charter to refrain from the threat or use of force in relation to ex-enemy states and, consequently, not to settle by peaceful means their disputes with ex-enemy states. The ex-enemy states have all the obligations which Article 2, Paragraph 6 imposes upon non-member states, but the member states have no substantial obligations in relation to the ex-enemy states. In this respect, the ex-enemy states are, in principle, ${ }^{21}$ outside of the law of the Charter. This outlawry is permanent;22 for according to the wording of Article 107, it is not terminated by the admission of an ex-enemy state to the Organization; and the definition of the term "enemy state" in Article 53, Paragraph 2 applies also to states after they have become members of the United Nations. All this was probably not intended and is politically hardly justifiable, but the text of the Charter does not correspond to the probably more reasonable intention of its authors. ${ }^{23}$

21. With the exception of certain rights conferred by Art. 2, I 6, Art. 11, I 2, Art. 32, Art. 35, I 2, and Art. 50, upon all non-member states, including ex-enemy states. However, see UNCIO Doc. 1095, III /3/50 (1945) 3 et seq.

22. In the Hearings at 303, the question arose as to whether the exception established by Art. 53, I 1 would apply in case a former enemy state would become a member of the United Nations. Mr. Pasvolsky answered this question as follows: "Presumably when any one of these nations becomes a Member of the Organization, this exception would no longer apply to it."

23. See Report to the President at 164. 